Dacie, J. V., and Lewis, S. M. (1970a). In Practical Haematology, 4th edn., p. 70. London, Churchill.

Dacie, J. V., and Lewis, S. M. (1970b). In Practical Haematology, 4th edn., p. 326. London, Churchill.

Douglas, A. S. (1964). In Anticoagulant Therapy, p. 279. Oxford, Blackwell Scientific.

Godal, H. C. (1962). Scandinavian fournal of Clinical and Laboratory Investigation, 14, 223.

Hardisty, R. M., and Hutton, R. A. (1965). British fournal of Haematology, $11,258$.

Hesse, V. E., Mink, I. B., Murphy, G. P., Moore, R. H., and Ambrus, J. L. (1970). New York fournal of Medicine, 70, 1851

Hocken, A. G., and Marwah, P. K. (1971). Lancet, 1, 164

Langdell, R. D., Wagner, R. U., and Brinkhous, K. M. (1963). Fournal of Laboratory and Clinical Medicine, 41, 637.

Larsson, S. O. (1971). Scandinavian fournal of Haematology, Suppl. No. 15, p. 1 .

Lawson, D. H., Will, G., Boddy, K., and Linton, A. L. (1968). Proceedings of the European Dialysis and Transplant Association, 5, 167.

Lindsay, R. M., et al., (1972). Clinical Nephrology. In press.

Lyman, D. J., Brash, J. L., Chaikin, S. W., Klein, K. G., and Carini, M. (1968). Transactions. American Society for Artificial Internal Organs, 14, 250.

Lyman, D. J., Brash, J. L., and Klein, K. G. (1969). Proceedings of the Artificial Heart Program Conference, $1,113$.

Mason, R. G., Shermer, R. W., and Zucker, W. H. (1972). Transactions. American Society for Artificial Internal Organs, 18, 32.
McNicol, G. P., Barakat, A. A., and Douglas, A. S. (1965). Scottish Medical fournal, 10, 189

McNicol, G. P., and Douglas, A. S. (1964). In Recent Advances in Clinical Pathology, ed. S. C. Dyke, p. 187. London, Churchill.

Merskey, C., Kleiner, G. J., and Johnson, A. J. (1966). Blood, 28, 1.

Muir, W. M., Lindsay, R. M., and Davidson, J. F. (1970). Proceedings of the European Dialysis and Transplant Association, 769.

Mylon, E., Winternitz, M. C., and de Süto-Nagy, G. T. (1942). fournal of Biological Chemistry, 143, 21.

Nilsson, I. M., and Olow, B. (1962). Acta Chirurgica Scandinavia, 123, 247.

Proctor, R. R., and Rapaport, S. I. (1961). American fournal of Clinical Pathology, 36, 212.

Ratnoff, O. D., and Menzie, C. (1964). In Blood Coagulation, Hemorrhage and Thrombosis, ed. L. M. Tocantins and L. A. Kazal, p. 224. New York, Grune and Stratton.

Remmert, L. F., and Cohen, P. P. (1949). Journal of Biological Chemistry, 187,431 .

Rodman, N. F., and Mason, R. G. (1970a). Thrombosis et Diathesis Haemorrhagica, Suppl. No. 40, p. 145.

Rodman, N. F., and Mason, R. G. (1970b). Thrombosis et Diathesis Haemorrhagica, Suppl. No. 42 , p. 61 .

Salzman, E. W., and Britten, M. B. (1965). In Haemorrhage and Thrombosis, p. 133, London, Churchill.

Salzman, E. W. (1971). Federation Proceedings, 30, 1705.

Shanberge, J. N., Matsuoka, T., and Fukui, H. (1967). American fournal of Clinical Pathology, 47, 533.

\title{
Comparative Evaluation of Water Recovery Test and Fluoroscopic Screening in Positioning a Nasogastric Tube during Gastric Secretory Studies
}

\author{
J. M. FINDLAY, R. J. PRESCOTT, W. SIRCUS
}

British Medical fournal, 1972, 4, 458-461

\section{Summary}

Acid secretion studies were carried out in $\mathbf{5 0}$ patients. Fluoroscopy or a modified water recovery test was used to position the nasogastric tube. For every patient each positioning procedure was used on one of two consecutive days, and acid output studies were performed. The tests were assessed by two observers and accepted or rejected. Analysis revealed no significant differences between the acid studies irrespective of the method used for positioning the nasogastric tube. Rejection rates by either procedure showed no significant difference. Practical considerations favour the continued use of water recovery as a means of positioning the nasogastric tube for gastric secretion studies.

\section{Introduction}

Two methods are investigated for positioning the nasogastric tube in patients undergoing tests of gastric secretion. Radiological, recommended by several groups (Levin et al, 1948; Johnston and McCraw, 1958; Marks, 1961; Baron, 1963) and an alternative, the water recovery test. With phenol red as a marker the recovery of $85-87 \%$ of swallowed water suggested that fluoroscopy may be unnecessary (Hassan and Hobsley, 1970).

The present study was designed to examine a modified water recovery test, and to compare and contrast it with the use of fluoroscopy.

Gastrointestinal Unit, Western General Hospital, Edinburgh J. M. FINDLAY, M.R.C.P., D.M.R.D., Senior Registrar in Medicine W. SIRCUS, M.D., F.R.C.P., Consultant Physician

Department of Social Medicine, University of Edinburgh R. J. PRESCOTT, M.SC., PH.D., Lecturer

\section{Patients and Methods}

Fifty patients were studied. None had undergone gastric surgery. They had a variety of upper-gastrointestinal disorders, and the determination of the gastric secretory response to pentagastrin was in the course of routine clinical investigations.

The patients were allocated to two groups using a procedure sequence determined by random selection from a pack of playing cards. Thus, 25 patients were allocated to each of the two groups-group $A$ with odd numbers and group $B$ with even numbers.

Standard Water Recovery Test.-A nasogastric tube (14 F. G. Levine $x$-ray opaque) was measured from the nose to a point $5 \mathrm{~cm}$ above the umbilicus by applying the tube to the body contour and by appropriate marking. The tube was then passed through the nose to this mark and aspiration was attempted. If unsuccessful, the tube position was adjusted until aspirate was obtained. Aspiration was then completed. The patient now drank $20 \mathrm{ml}$ of water and lay in a semirecumbent position on the left side. If between 16 and 20 $\mathrm{ml}$ of water could then be recovered by using manual aspiration with a syringe the position of the tube was regarded as satisfactory. If not, the patient was first turned supine and then into the right lateral position. If adequate recovery was still not achieved the tube was withdrawn in $2.5-\mathrm{cm}$ stages, and was regarded as being in satisfactory position when 16 to $20 \mathrm{ml}$ were recovered in toto.

\section{PROCEDURE}

Group A.-A "standard water recovery test" was performed. When a satisfactory tube position had been achieved the tube was secured to the nose with adhesive tape. The patient then went to the $x$-ray department. A plain radiograph of the abdomen was taken and the patient returned to the laboratory for the ensuing acid output test. No information regarding 
the tube position was given to the technical nurses carrying out the tests. On the next day the patient returned for a repeat test. The tube was again passed into the stomach through the nose but one of us (J.M.F.) screened it into the position described as "optimum" (Hassan and Hobsley, 1970) for recovery of secretions, and secured it to the nose with adhesive tape. The patient returned to the laboratory and the water recovery test was repeated. Any movements of the tube required to obtain satisfactory water recovery were recorded. The acid output test was then carried out.

Group B.-The procedures were carried out in the reverse order. On the first day the tube was screened to the "optimum" position and the water recovery test was carried out. Movement of the tube to obtain satisfactory water recovery was again recorded and the acid output study followed. On the next day the "standard water recovery test" was followed immediately by a radiograph recording the position in which the tube rested. The film and the result were not available to those conducting the subsequent study of gastric secretion. An acid output test was then performed.

\section{PENTAGASTRIN TEST}

After the tube had been positioned either by fluoroscopy or water recovery and aspiration again repeated, continuous suction aspiration of the secretions from the unstimulated stomach for one hour was followed by the subcutaneous injection of pentagastrin (Peptavlon) in a dose of $0.6 \mu \mathrm{g} / \mathrm{kg}$ body weight. The injection site was massaged. Aspiration used a combination of low pressure vacuum suction and the intermittent manual operation of a syringe. The aspirate was collected in four batches, each of 20 minutes' duration.

Acidity was titrated with $\mathrm{N} / 10 \mathrm{NaOH}$ to $\mathrm{pH} 7$ (Titration and AutoBurette: Radiometer, Copenhagen). The colour of the aspirate was noted for each 20 minute period. The test results were recorded on sheets for eventual inclusion in the patient's notes, and copies were retained and allocated a number by a random procedure. All evidence of identity was removed by cutting off the subject data-recording section of the test sheets.

When the 100 tests were completed the records were shuffled and passed to a physician and a surgeon with special experience of gastric secretion methodology. The scrutineers worked separately, and were asked to reject any test that they regarded as being unsatisfactory. The records were subsequently shuffled a second time and the same scrutineers were asked to reassess the tests. The grounds for rejecting tests were recorded in each instance.

\section{REJECTION OF TESTS BY SCRUTINEERS}

On the first assessment by the physician 13 of the 100 tests were rejected. On the second assessment also 13 tests were rejected. Eight of these 13 were rejected in both reviews.

On the first assessment by the surgeon 10 tests were rejected, on the second 17 . Seven tests were rejected in both reviews.

The grounds for rejection were stated to be evidence of faulty aspiration such as when a larger volume was obtained in the fourth rather than in the third periods, gross contamination by bile or blood, and a larger recovery in the basal hours suggesting incomplete aspiration of the fasting contents of the stomach.

\section{CONSIDERATION OF THE “OPTIMUM" POSITION}

In 48 of 50 "standard water recovery tests" films were available to assess the position of the tube as two radiographs were damaged in processing. In this group in which 36 of the tests passed the scrutineers, the tube was in the fundus in
18 , in the body in 3, in the "optimum" position in 14, and actually in a hernial sac in 1 test. The two water recovery tests with damaged radiographs passed the scrutineers.

\section{Results}

\section{COMPARISONS OF LEVELS OF RESPONSE}

The following analysis is based on those individuals where positioning of the tube by screening and by the "standard water recovery test" both led to acid outputs which were acceptable to the scrutineer. We asked the following questions. (1) Was there evidence of an order effect-that is, did the test performed second give significantly higher or lower results than in the first? (2) Did either method of positioning lead to systematically higher or lower results? As each individual had been tested after both the "standard water recovery test" and the screening procedure, leading to paired sets of acid outputs, an analysis based on the differences between these pairs was appropriate. An analysis of variance (Table I) showed that neither the method of positioning (water or screen) nor the order of the test (first or second) had any significant effect on the level of response $(P>0.9)$.

TABLE I-Analysis of Variance of Acid Outputs Obtained from 16 Patients Giving Acceptable Acid Outputs After Fluoroscopy Without Repositioning and after the "Standard Water Recovery Test"

\begin{tabular}{|c|c|c|c|c|c|c|}
\hline \multicolumn{3}{|c|}{ Source of Variation } & $\begin{array}{l}\text { Degrees of } \\
\text { Freedom }\end{array}$ & $\begin{array}{l}\text { Sums of } \\
\text { Squares }\end{array}$ & $\begin{array}{l}\text { Mean } \\
\text { Square }\end{array}$ & $\mathbf{F}$ \\
\hline $\begin{array}{l}\text { Between methods } \\
\text { Order effect. . } \\
\text { Residual } \quad .\end{array}$ & $\begin{array}{l}\cdots \\
\cdots \\
\cdots\end{array}$ & $\begin{array}{l}\cdots \\
\cdots \\
\cdots\end{array}$ & $\begin{array}{r}1 \\
1 \\
14\end{array}$ & $\begin{array}{r}0.53 \\
0.53 \\
453.55\end{array}$ & $\begin{array}{r}0.53 \\
0.53 \\
32.40\end{array}$ & $\begin{array}{l}0.02 \\
0.02\end{array}$ \\
\hline Total & . & . & 16 & $454 \cdot 61$ & & \\
\hline
\end{tabular}

\section{COMPARISON OF VARIATION}

If either test gave rise to a considerably greater degree of variation this might be reflected in the overall variance shown in the results from this test. Therefore, we compared the overall variance given by the "standard water recovery test" with the overall variance given by the screen test. The usual $F$ test of significance was inappropriate because of the lack of independence between the two sets of results. A suitable procedure for the comparison of two correlated variances due to Pitman (1939) is described by Snedecor and Cochran (1967). By using the notation of Snedecor and Cochran we obtained $\mathrm{rDS}=0.06$, d.f. $=28, \mathrm{P}>0.7$.

This provides no suggestion that the variances given by the two methods differ.

It was necessary in 19 patients (see Table II) to move the tube after screening to a new position in which it would pass the "water recovery test." Of these, 14 gave two acid output results that were acceptable to the scrutineers. As movement was necessary after screening for these patients the positioning in both of their acid output tests had been "effective" by the "standard water recovery test." The difference in acid output between the pairs of tests formed a basis for demon-

TABLE II-Rejection of Acid Output Results

\begin{tabular}{|c|c|c|c|}
\hline \multirow{2}{*}{$\begin{array}{l}\text { Water Recovery Test After } \\
\text { Positioning by Screening }\end{array}$} & \multirow{2}{*}{$\begin{array}{l}\text { Scrutineer } \\
\text { Decision }\end{array}$} & \multicolumn{2}{|c|}{$\begin{array}{l}\text { Result of Corresponding } \\
\text { "Standard Water Recovery Test" }\end{array}$} \\
\hline & & Accepted & Rejected \\
\hline $\begin{array}{l}\text { Satisfactory recovery without } \\
\text { movement }(n=31) \\
\text { Unsatisfactory recovery without } \\
\text { further movement }(n=19)\end{array}$ & $\begin{array}{lr}\text { Accepted } & 20 \\
\text { Rejected } & 11 \\
\text { Accepted } & 18 \\
\text { Rejected } & 1\end{array}$ & $\begin{array}{r}16 \\
7 \\
14 \\
1\end{array}$ & $\begin{array}{l}4 \\
4 \\
4 \\
0\end{array}$ \\
\hline & Total & 38 & 12 \\
\hline
\end{tabular}


strating the reproducibility of the "standard water recovery test."

There were 16 patients who achieved an acceptable acid output test after both positioning of the tube by screening and by the "standard water recovery test" (Table III). For each of these 16 the difference in response between the two tests provided a combined measure of the reproducibility after both positioning procedures. One can establish that if the screened test led to better reproducibility than the "standard water recovery test" the differences shown by the latter group of 16 subjects would tend to be lower than the differences given by the 14 subjects undergoing what was, in effect, two "standard water recovery tests." Wilcoxon's test showed no statistically significant difference between the two groups $(\mathrm{P}>0 \cdot 1)$.

TABLE III-Results of Acid Output Tests in Two Groups of Patients with Gastrointestinal Disorders

\begin{tabular}{|c|c|c|c|c|c|c|}
\hline $\begin{array}{l}\text { Test } \\
\text { No. }\end{array}$ & $\begin{array}{c}\text { Maximal } \\
\text { Acid } \\
\text { Output } \\
\text { by } \\
\text { Water } \\
\text { Recovery } \\
\text { (mEq) }\end{array}$ & $\begin{array}{c}\text { Position } \\
\text { on } \\
\text { Plain } \\
\text { Film }\end{array}$ & $\begin{array}{c}\text { Maximal } \\
\text { Acid } \\
\text { Output } \\
\text { after } \\
\text { Fluoro- } \\
\text { scony } \\
\text { (mEq) }\end{array}$ & $\begin{array}{c}\text { Maximal } \\
\text { Acid } \\
\text { Output } \\
\text { after } \\
\text { Screening } \\
\text { and } \\
\text { Subsequent } \\
\text { Water } \\
\text { Recovery } \\
\text { (mEq) }\end{array}$ & $\begin{array}{c}\text { Extent of } \\
\text { Tube } \\
\text { Movement } \\
\text { Required } \\
\text { to Obtain } \\
\text { Adequate } \\
\text { Recovery } \\
\text { (cm) }\end{array}$ & $\begin{array}{l}\text { Acceptable } \\
\text { by Both } \\
\text { Methods } \\
\text { (No/Yes) }\end{array}$ \\
\hline \multicolumn{7}{|c|}{ Group $A$} \\
\hline $\begin{array}{r}1 \\
2 \\
3 \\
4 \\
5 \\
6 \\
7 \\
8 \\
9 \\
10 \\
11 \\
12 \\
13 \\
14 \\
15 \\
16 \\
17 \\
18 \\
19 \\
20 \\
21 \\
22 \\
23 \\
24 \\
25\end{array}$ & $\begin{array}{l}31 \cdot 7 \\
30 \cdot 0 \\
34 \cdot 1 \\
29 \cdot 2 \\
33 \cdot 8^{*} \\
17 \cdot 0 \\
19 \cdot 8 \\
30 \cdot 2 \\
26.3 \\
33 \cdot 9 \\
35 \cdot 5 \\
32 \cdot 0 \\
28 \cdot 3^{*} \\
31 \cdot 1 \\
42 \cdot 9 \\
17 \cdot 7 \\
20 \cdot 1^{*} \\
46 \cdot 5 \\
74 \cdot 5 \\
3 \cdot 6^{*} \\
11 \cdot 7 \\
49 \cdot 1 \\
29 \cdot 1 \\
1 \cdot 0^{*} \\
35 \cdot 1\end{array}$ & $\begin{array}{c}\text { Optimum } \\
\text { Body } \\
\text { Fundal } \\
\text { Body } \\
\text { Fundal } \\
\text { Fundal } \\
\text { Fundal } \\
\text { Fundal } \\
\text { Fundal } \\
\text { Fundal } \\
\text { Optimum } \\
\text { Fundal } \\
\text { Fundal } \\
\text { Fundal } \\
\text { Fundal } \\
\text { Optimum } \\
\text { Body } \\
\text { Optimum } \\
\text { Optimum } \\
\text { Fundal } \\
\text { Optimum } \\
\text { Optimum } \\
\text { Fundal } \\
\text { Optimum } \\
\text { Fundal }\end{array}$ & $\begin{array}{l}27 \cdot 0 \\
24 \cdot 9 * \\
\bar{Z} \\
28 \cdot 3 \\
\overline{-} \\
\overline{23 \cdot 4} \\
39 \cdot 5 \\
34 \cdot 6 \\
34 \cdot 5 \\
\overline{23 \cdot 7} \\
32 \cdot 0 \\
31 \cdot 6 \\
52 \cdot 6 * \\
20 \cdot 6 \\
\overline{51 \cdot 3} \\
29 \cdot 4 \\
6 \cdot 2^{*} \\
34 \cdot 0\end{array}$ & $\begin{array}{l}\bar{Z} \\
35 \cdot 6^{*} \\
33 \cdot 0 \\
\overline{15 \cdot 4} \\
20 \cdot 6 \\
25 \cdot 0 \\
\bar{Z} \\
\overline{\bar{Z}} \\
\frac{24 \cdot 5}{\bar{Z}} \\
\overline{28 \cdot 2} \\
\overline{65 \cdot 5} \\
\overline{11 \cdot 1} \\
\bar{Z} \\
\bar{Z}\end{array}$ & 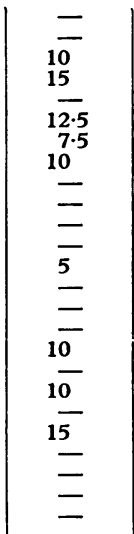 & $\begin{array}{l}\text { Yes } \\
\text { No } \\
\text { No } \\
\text { No } \\
\text { No } \\
\text { No } \\
\text { No } \\
\text { No } \\
\text { Yes } \\
\text { Yes } \\
\text { Yes } \\
\text { Yes } \\
\text { No } \\
\text { Yes } \\
\text { Yes } \\
\text { Yes } \\
\text { No } \\
\text { No } \\
\text { No } \\
\text { No } \\
\text { No } \\
\text { Yes } \\
\text { Yes } \\
\text { No } \\
\text { Yes }\end{array}$ \\
\hline $\begin{array}{l}\text { No. of tests } \\
\text { rejected in } \\
\text { group A }\end{array}$ & 5 & & 3 & 1 & & \\
\hline \multicolumn{7}{|c|}{ Group B } \\
\hline $\begin{array}{r}1 \\
2 \\
3 \\
4 \\
5 \\
6 \\
7 \\
8 \\
9 \\
10 \\
11 \\
12 \\
13 \\
14 \\
15 \\
16 \\
17 \\
18 \\
19 \\
20 \\
21 \\
22 \\
23 \\
24 \\
25\end{array}$ & $\begin{array}{l}25 \cdot 3 \\
32 \cdot 3 \\
14 \cdot 5 \\
9 \cdot 7^{*} \\
22 \cdot 8^{*} \\
13 \cdot 9^{*} \\
48 \cdot 8 \\
43 \cdot 8^{*} \\
46 \cdot 4 \\
34 \cdot 8 \\
34 \cdot 8^{*} \\
18 \cdot 8 \\
27 \cdot 4 \\
15 \cdot 7^{*} \\
12 \cdot 6 \\
33 \cdot 8 \\
36 \cdot 0 \\
36 \cdot 6 \\
3 \cdot 5 \\
36 \cdot 6 \\
8 \cdot 8 \\
33 \cdot 3 \\
36 \cdot 6 \\
42 \cdot 5 * \\
28 \cdot 2\end{array}$ & \begin{tabular}{|c} 
Optimum \\
Optimum \\
Fundal \\
Optimum \\
Optimum \\
Optimum \\
Optimum \\
Fundal \\
Optimum \\
Optimum \\
Optimum \\
Optimum \\
Optimum \\
In hernial sac \\
Fundal \\
Fundal \\
Fundal \\
Fundal \\
Fundal \\
Fundal \\
Body \\
Fundal \\
Optimum
\end{tabular} & $\begin{array}{c}2 \cdot 1^{*} \\
29 \cdot 1^{*} \\
17 \cdot 8^{*} \\
2 \cdot 0^{*} \\
30 \cdot 4^{*} \\
15 \cdot 0 \\
34 \cdot 5^{*} \\
44 \cdot 5 \\
48 \cdot 3 \\
= \\
19 \cdot 9 \\
= \\
10 \cdot 6^{*} \\
= \\
= \\
35 \cdot 3 \\
9 \cdot 5 \\
30 \cdot 9 \\
43 \cdot 5^{*} \\
-\end{array}$ & $\begin{array}{l}= \\
= \\
= \\
= \\
\bar{Z} \\
42 \cdot 6 \\
37 \cdot 2 \\
24 \cdot 6 \\
22 \cdot 0 \\
\overline{39 \cdot 2} \\
37 \cdot 5 \\
17 \cdot 9 \\
2 \cdot 3 \\
\bar{Z} \\
\overline{37 \cdot 0} \\
\overline{35 \cdot 5} .\end{array}$ & $\begin{array}{l}= \\
= \\
= \\
= \\
\bar{Z} \\
10 \\
10 \\
20 \\
7 \cdot 5 \\
7 \cdot 5 \\
12 \cdot 5 \\
\frac{7 \cdot 5}{Z} \\
\bar{Z} \\
2.5 \\
10\end{array}$ & $\begin{array}{l}\text { No } \\
\text { No } \\
\text { No } \\
\text { No } \\
\text { No } \\
\text { No } \\
\text { No } \\
\text { No } \\
\text { Yes } \\
\text { No } \\
\text { No } \\
\text { Yes } \\
\text { No } \\
\text { No } \\
\text { No } \\
\text { No } \\
\text { No } \\
\text { No } \\
\text { No } \\
\text { Yes } \\
\text { Yes } \\
\text { Yes } \\
\text { No } \\
\text { No } \\
\text { No }\end{array}$ \\
\hline $\begin{array}{l}\text { No. of tests } \\
\text { rejected in } \\
\text { group B }\end{array}$ & 7 & & 8 & 0 & & \\
\hline
\end{tabular}

* Tests reiected by scrutineers.

\section{REJECTED CASES}

It was of great importance to determine whether either method of positioning led to a higher rejection rate. There were several facets of this question which could be examined. A summary of the rejections appears in Table II.
After screening, 31 of the 50 subjects passed the water recovery test without movement of the tube. Of these 31 tests, 11 were rejected by the scrutineers compared to 8 rejections in the corresponding 31 tests after positioning by the "standard water recovery test." This difference was not statistically significant $(P>0 \cdot 5)$. One could alternatively look at the rejection rate for the combined procedure of screening plus any necessary movement and compare this to the rejection rate for the "standard water recovery test." In both cases 12 of the 50 tests were rejected. Thirdly, we studied the subjects where movement of the tube was necessary after screening. In this group 19 results were available for comparison. One test after tube movement was rejected compared with four rejections after the "standard water recovery tests." These differences were again not statistically significant $(P>0.3)$.

In an experiment of this type where a large amount of data had been rejected it was important to verify that the criteria for rejection had not materially affected the conclusions. When the rejected cases were added to the results for analysis of levels of response and comparison of variation the same conclusions as above were reached with no appreciable changes in the levels of significance.

\section{Discussion}

This study set out to compare and contrast water recovery and fluoroscopy in the satisfactory positioning of tubes for acid output studies. It is axiomatic that as the outputs studied were "maximal" where one procedure had a significantly higher acid yield then it was deemed to be the more satisfactory test.* No significant difference occurred in this study in "accepted" or "rejected" results.

Hassan and Hobsley imply that precise positioning is not crucial provided water recovery is achieved. They opted for the most proximal position in which they recovered 16 to 20 $\mathrm{ml}$ of swallowed water. We felt a simplified approach needed evaluation. We modified their procedure by settling for the most distal position in which we could aspirate 16 to $20 \mathrm{ml}$ of water. This, in fact, was the first position in which the water recovery was satisfactory. We did not give any additional $20 \mathrm{ml}$ of water.

No significant difference appears in the results obtained by using either water recovery or fluoroscopical control. We believe, therefore, that practical differences in performing these tests strongly favour the routine use of the water recovery method. Satisfactory tests can be achieved without the patient leaving the ward or laboratory, and tests may be carried out in pregnancy when fluoroscopy is inadvisable.

Fluoroscopy has other disadvantages. The equipment is expensive and not available in all hospitals, particularly in developing countries. In hospital the screening imposes an extra burden on a radiological department early in the working day coincidental with the peak load on radiological (screening) and portering services.

The high rejection rate of tests-24 out of 100-requires a note of explanation. The scrutineers both commented that they had rejected tests which they felt in clinical practice would probably have been deemed good enough not to require repetition. They felt obliged to reject any tests that did not match up to the strictest criteria in a study such as this. When all the rejected tests were included, however, the conclusions remained unaltered.

* "Maximal" acid output is defined as the total titratable acid (volume $\times$ concentration) secreted in the 60 minutes subsequent to the injection of pentagastrin in a dose calculated to stimulate secretion to a level which, for all practical purposes, renders the test reproducible. It should be noted that neither "maximal" acid nor "peak acid output" necessarily represents the maximal secretory capacity of the stomach which, in different investigative conditions, may be much larger. 


\section{Conclusions}

The water recovery test as described is as satisfactory a means of positioning a nasogastric tube for gastric secretion tests as fluoroscopy.

Practical considerations strongly favour the use of the water recovery test for tube positioning.

We wish to acknowledge the help of Mrs. I. Craig and Mrs. M. Flint (staff nurses) in carrying out the tests, of Mr. C. V. Ruckley for scrutinizing the test results, of Dr. D. H. Cummack for radio logical services, and of Mr. D. R. Rundell for performing statistical calculations.

\section{References}

Baron, J. H. (1963). Gut, 4, 136

Hassan, M. A., and Hobsley, M. (1970). British Medical fournal, 1, 458.

Johnston, D. H., and McCraw, B. H. (1958). Gastroenterology, 35, 512.

Levin, E., Kirsner, J. B., Palmer, W. L., and Butler, C. (1948). Gastroenterology, 10, 939.

Marks, I. N. (1961). Gastroenterology, 41, 599.

Pitman, E. J. G. (1939). Biometrika, 31,9.

Snedecor, G. W., and Cochran, W. G. (1967). Statistical Methods, 6th edn., p.195. Iowa, State University Press.

\title{
Induction of Labour by Simultaneous Intravenous Administration of Prostaglandin $\mathrm{E}_{2}$ and Oxytocin
}

\author{
WILLIAM C. M. K. NAISMITH， WALLACE BARR，J. MACVICAR
}

British Medical fournal, 1972, 4, 461-462

Summary

In a group of 20 matched primigravid patients labour was induced by forewater amniotomy followed by intravenous oxytocin (Syntocinon) administered in escalating doses. Ten of these patients, in a double-blind trial, also received prostaglandin $E_{2}$ infused simultaneously with the oxytocin. In the combined prostaglandin-oxytocin group there was a noticeable reduction in the dosage of oxytocin required to produce effective uterine action, and the duration of labour was also reduced. No side effects were observed.

\section{Introduction}

This trial was designed to assess the possible value of combining intravenous prostaglandin $\mathrm{E}_{2}$ with oxytocin (Syntocinon) as a means of inducing labour after amniotomy.

\section{Patients and Methods}

Twenty patients were included in the series. That is, the patients were all healthy primigravidae aged less than 30 years with a live singleton pregnancy and the fetus presenting by the head. The only obstetrical abnormality was that all the pregnancies were at least seven days past the expected date of confinement.

Forewater amniotomy was performed initially in all cases. Immediately thereafter an intravenous infusion of oxytocin was begun at a rate of $0.66 \mathrm{mU} / \mathrm{min}$. This rate was doubled every 15 minutes until adequate uterine response was produced, as adjudged by clinical observation.

In all patients, and simultaneously with the start of the oxytocin, an infusion was administered by a Palmer pump through a micropore filter into the same intravenous cannula. This solution was either prostaglandin $\mathrm{E}_{2}$ or a placebo (normal saline), the choice of solution being made in the hospital pharmacy by drawing lottery cards on a random basis. The solutions were

Queen Mother's Hospital, Glasgow

WILLIAM C. M. K. NAISMITH, M.B., M.R.C.o.G., Senior Registrar

WAILACE BARR, F.R.C.S., F.R.C.O.G., Consultant Öbstetrician

J. MACVICAR, M.D., F.R.C.S., Senior Lecturer delivered to the labour suite in identical containers and were indistinguishable. A constant Palmer pump setting was used throughout labour for all cases so that the rate of a prostaglandin $\mathrm{E}_{2}$ infusion would be $0.5 \mu \mathrm{g} / \mathrm{min}$.

\section{Results}

Oxytocin Rate.-The mean maximum oxytocin rate of infusion in the oxytocin-prostaglandin group was appreciably less than in the group given oxtyocin alone: $16.9 \mathrm{mU} / \mathrm{min} \pm 3.7 \mathrm{~S} . \mathrm{D}$. (range $5-43$ ) and $71 \cdot 4 \mathrm{mU} / \mathrm{min} \pm 19 \cdot 1$ S.D. (range 11-213) respectively. This difference in rate is highly significant $(\mathrm{P}<0.025)$.

Duration of Labour.-The mean duration of labour in the oxytocin-prostaglandin group was less than in the oxytocinplacebo group: $453 \mathrm{~min}$ (range 278-823) and $591 \mathrm{~min} \pm 63$ S.D. (range 331-827) respectively. However, this difference is not significant $(P>0.05)$.

Delivery.-One patient in the oxytocin-placebo group was delivered by caesarean section. After a labour lasting $11 \mathrm{hr}$ 50 min full cervical dilatation had not been achieved, and both clinically and radiographically there was cephalopelvic disproportion of a minor degree. Fetal distress did not occur. The remaining 19 patients in the series were all delivered by the vagina though seven of the oxytocin-prostaglandin group and five of the oxytocin-placebo group required instrumental assistance by forceps or vacuum extractor.

Neonatal Status.-There was no perinatal death and no neonatal morbidity in the series. Two of the babies delivered by the combined infusion had low Apgar scores ( 2 at two minutes and 2 and 4 respectively at five minutes). Both these babies were delivered spontaneously with no intrapartum signs of fetal distress. Neonatal asphyxia was diagnosed in both babies. After routine resuscitation, both progressed normally and were discharged from the special care nursery after routine observation for 24 hours.

Side Effects.-There was no significant side effect observed in the series. This is of interest since nausea, vomiting, and diarrhoea occur not infrequently with prostaglandin and can, in a small proportion of cases, be troublesome to the patient. Three of the oxytocin-prostaglandin patients developed very slight venous erythema proximal to the infusion cannula.

\section{Discussion}

Induction of labour by amniotomy followed by intravenous oxytocin administered in escalating doses is now a well-estab- 